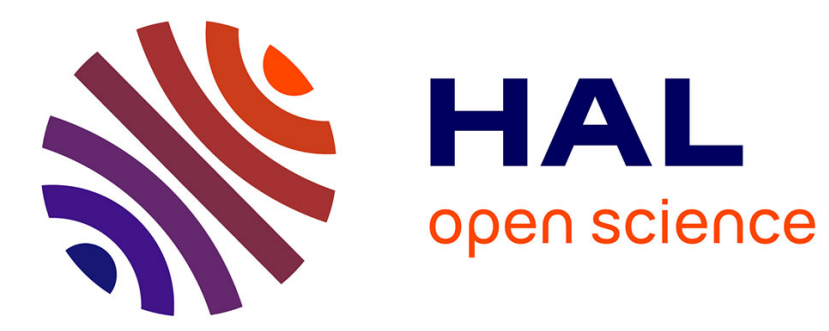

\title{
Alkaline extraction of xyloglucan from depectinised apple pomace: optimisation and characterisation
}

\author{
C. Renard, C. Lemeunier, Jean-François Thibault
}

\section{To cite this version:}

C. Renard, C. Lemeunier, Jean-François Thibault. Alkaline extraction of xyloglucan from depectinised apple pomace : optimisation and characterisation. Carbohydrate Polymers, 1995, 28, pp.209-216. hal02714450

\author{
HAL Id: hal-02714450 \\ https://hal.inrae.fr/hal-02714450
}

Submitted on 1 Jun 2020

HAL is a multi-disciplinary open access archive for the deposit and dissemination of scientific research documents, whether they are published or not. The documents may come from teaching and research institutions in France or abroad, or from public or private research centers.
L'archive ouverte pluridisciplinaire HAL, est destinée au dépôt et à la diffusion de documents scientifiques de niveau recherche, publiés ou non, émanant des établissements d'enseignement et de recherche français ou étrangers, des laboratoires publics ou privés.

\section{(c)(2)}

Distributed under a Creative Commons CCO - Public Domain Dedication| 4.0 International 


\title{
Alkaline extraction of xyloglucan from depectinised apple pomace: optimisation and characterisation
}

\author{
C.M.G.C. Renard*, C. Lemeunier \& J.-F. Thibault \\ Laboratoire de Biochimie et Technologie des Glucides, INRA, B.P. 1627, 44316 Nantes cédex 03, France
}

(Received 20 April 1995; revised version received 30 August 1995; accepted 31 August 1995)

\begin{abstract}
Alkaline extraction of xyloglucans from depectinised apple pomace was studied using a fractional factorial experimental design. The extraction parameters tested were: concentration $(1-4 \mathrm{M})$ and type $(\mathrm{NaOH}$ and $\mathrm{KOH})$ of alkali, duration of extraction $(2-16 \mathrm{~h})$, temperature $\left(0-40^{\circ} \mathrm{C}\right)$ and presence or absence of $\mathrm{NaBH}_{4}$. Alkali concentration and duration of extraction were the most significant parameters, and could be related to yields in a first degree model. Increase of the duration of extraction and of the alkali concentration increased the yield. The model was confirmed using intermediate and higher concentrations, and by constructing a time curve of the extraction.

Xyloglucans were extracted on a larger scale using the optimal conditions defined and a second extract was obtained by washing the residue with water. Both were rich in proteins ( 441 and $247 \mathrm{mg} / \mathrm{g}$, respectively). The major polysaccharide of the alkali-soluble material was a fucogalactoxyloglucan, as confirmed by its degradation products with an endoglucanase. The water-soluble material contained little or no xyloglucan.
\end{abstract}

\section{INTRODUCTION}

Xyloglucans are one of the main hemicelluloses from primary cell walls of dicots (McNeil et al., 1984; Hayashi, 1989), and more specifically, of the cell walls of apple fruit (Renard et al., 1991, 1992). They are mostly present in the cell walls as fucogalactoxyloglucans, which are composed of a cellulose-like backbone of 1,4 linked $\beta$-D-glucopyranose residues, of which $\sim 75 \%$ carry side-chains attached to positions 6 . The main sidechains are $\alpha$-D-xyl $p-(1 \rightarrow, \beta$-D-gal $p-(1 \rightarrow 2)-\alpha$-D-xyl $p-(1 \rightarrow$, and $\alpha$-L-fuc $p(1 \rightarrow 2)-\beta$-D-gal $p-(1 \rightarrow 2)-\alpha$-D-xylp- $(1 \rightarrow$. The structure of the xyloglucans is characterised by a repeating unit composed of four glucose residues, of which three are substituted. In primary cell walls of elongating tissues, xyloglucans play an important role in regulation of growth. They are both a source of oligosaccharides which can have anti-auxin activity (McDougall \& Fry, 1989) and the most likely candidates for controlling the 'creep' of cellulose microfibrils. They are hydrogen-bonded to cellulose microfibrils and, in growing tissues, subjected to the action of endoxyloglucan transferase (EXT) (Fry et al., 1992; Nishitani \& Tominaga, 1992). In addition, some plants,

*Author to whom correspondence should be addressed. mostly legumes, e.g. tamarind, contain in their seeds thickened cell walls rich in 'amyloid' xyloglucans (Kooiman, 1960), devoid of fucose, which they use as storage polysaccharides. These amyloid xyloglucans can be extracted relatively easily and have good thickening and gel-forming properties (Rao, 1959).

Xyloglucans from primary cell walls are typical hemicelluloses, tightly bonded to cellulose by hydrogen bonds. They are most often extracted by concentrated (1 or $4 \mathrm{M}$ ) aqueous $\mathrm{KOH}$ or $\mathrm{NaOH}$ at room temperature, after extraction of pectins by chelating agents, hot acid treatment or dilute alkali, but there are few systematic studies on their extraction conditions. Edelman \& Fry (1992) found that extraction of xyloglucans from the primary cell walls of suspension-cultured rose cells was dependent on the temperature, with $6 \mathrm{M} \mathrm{NaOH}$ as the most efficient extractant at $25^{\circ} \mathrm{C}$. They also found very slow kinetics of extraction, with only $25-30 \%$ solubilised after $24 \mathrm{~h}$, and an extraction duration of up to 2-3 weeks. They also reported that after an initial treatment with concentrated alkali, water extracted more material than another treatment with alkali.

During earlier studies on the structure of apple cell walls, we found (Renard et al., 1991, 1992) that their hemicelluloses were mostly fucogalactoxyloglucans, which could be extracted by sequential extraction with 
1 and $4 \mathrm{M} \mathrm{NaOH}$, or by endoglucanase digestion. They represented up to $18 \%$ of these cell walls, and were composed of similar amounts of three repeating units, $\quad[\mathrm{Xyl}(\mathrm{Glc})]_{3}-\mathrm{Glc}, \quad[\mathrm{Xyl}(\mathrm{Glc})]_{2}$-(FucGalXyl)GlcGlc and XylGlc-(GalXyl)Glc-(FucGalXyl)Glc-Glc. Apple pomace is the residue from cider and apple juice manufacture, and is further used as a source of pectins. The xyloglucans are not solubilised during the hot dilute acid treatments used for pectin extractions and persist in depectinised pomaces. In order to find a use for these depectinised apple pomace, we have studied the extraction of their xyloglucans, their physico-chemical properties and their structure. A fractional factorial experimental design was used to optimise the yield; xyloglucans were extracted on a larger scale for characterisation of their structure and properties.

\section{MATERIALS AND METHODS}

\section{Materials}

Depectinised apple pomace was obtained from the pectin plant of SBI in Redon (France). Cellulase (endoB-(1,4)-glucanase) and tamarind xyloglucan were from Megazyme (Australia); protease was from Bacillus licheniformis (Sigma P5380).

\section{Extraction of xyloglucans}

\section{Optimisation}

One gram of depectinised apple pomace was suspended in the alkali solution $(100 \mathrm{ml})$ under magnetic stirring. After a given time, the slurry was centrifuged $(15,000 \mathrm{~g}$, $15 \mathrm{~min}$ ); the extract was neutralised with acetic acid and the residue was re-extracted in the same conditions. After the second extraction, the residue was washed with distilled water until the washings were at $\sim \mathrm{pH} 7$ and freeze-dried. The extracts were pooled and dialysed against distilled water, then freeze-dried. The extraction conditions for the different extracts are given in Table 1.

\section{Kinetics of solubilisation}

Kinetics studies were carried out using $50 \mathrm{mg}$ samples of apple pomace suspended in $5 \mathrm{ml}$ of $4 \mathrm{M} \mathrm{KOH}$ (with $\mathrm{NaBH}_{4}$ ) on a rotating wheel at $40^{\circ} \mathrm{C}$. Extraction times of $1,2,4,8,16,24$ and $48 \mathrm{~h}$ were tested in duplicate. Extraction was stopped by centrifugation (3000g, 7 $\mathrm{min}$ ) and the extracts were neutralised and dialysed.

\section{Preparative extraction}

Twenty grams of apple pomace were suspended in 21 of $4 \mathrm{M} \mathrm{KOH}$ at $40^{\circ} \mathrm{C}$ for $16 \mathrm{~h}$, under magnetic stirring. After centrifugation $(10,000 \mathrm{~g}, 20 \mathrm{~min})$, the supernatant was neutralised, dialysed and freeze-dried, giving the ASM (alkali-soluble material) fraction. The residue was washed by water until the washing water was neutral. The washings were pooled, neutralised, dialysed and freeze-dried, yielding the WSM (water-soluble material) fraction.

\section{Ion-exchange chromatography}

A column of DEAE Sepharose CL-6B $(20 \times 2 \mathrm{~cm})$ was equilibrated with $0.05 \mathrm{M}$ sodium acetate buffer $(\mathrm{pH} 4.8)$. A solution of $20 \mathrm{ml}$ of polysaccharides $(\sim 100 \mathrm{mg})$ in sodium acetate buffer $(0.05 \mathrm{M}, \mathrm{pH} 4.8)$ was loaded onto the column and the column eluted with $100 \mathrm{ml}$ of $0.05 \mathrm{M}$ acetate buffer $(\mathrm{pH} 4.8)$ at $60 \mathrm{ml} / \mathrm{h}$. Bound material was then eluted using a linear gradient $(200 \mathrm{ml}, 0.05-1 \mathrm{M}$

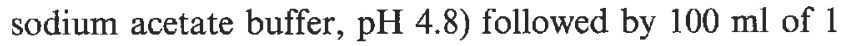
$\mathrm{M}$ sodium acetate buffer. Fractions $(5 \mathrm{ml})$ were collected and assayed for acidic and neutral sugars as described below (see Analytical section).

\section{Gel-filtration chromatography}

A column of Bio-Gel P-4 and a column of Bio-Gel P-2 $(2.5 \times 90 \mathrm{~cm}$ each) were eluted in series by distilled water

Table 1. Conditions of extraction and coding of the extracts

\begin{tabular}{|c|c|c|c|c|c|}
\hline $\begin{array}{l}\text { Variable } \\
\text { no. of } \\
\text { variable }\end{array}$ & $\begin{array}{c}\text { Molarity } \\
\text { of alkali } \\
1\end{array}$ & $\begin{array}{c}\text { Temperature } \\
\left({ }^{\circ} \mathrm{C}\right) \\
2\end{array}$ & $\underset{3}{\text { Time }}(\mathrm{h})$ & $\begin{array}{c}\mathrm{NaBH}_{4} \\
(\mathrm{~mol} / \mathrm{l}) \\
4\end{array}$ & $\begin{array}{c}\text { Type } \\
\text { of alkali } \\
5\end{array}$ \\
\hline $\begin{array}{l}-1 \\
+1\end{array}$ & $\begin{array}{l}1 \mathrm{M} \\
4 \mathrm{M}\end{array}$ & $\begin{array}{c}0 \\
40\end{array}$ & $\begin{array}{c}2 \\
16\end{array}$ & $\begin{array}{c}0 \\
0.026\end{array}$ & $\begin{array}{l}\mathrm{NaOH} \\
\mathrm{KOH}\end{array}$ \\
\hline $\begin{array}{l}\text { L0 } \\
\text { L1 } \\
\text { L2 } \\
\text { L3 } \\
\text { L4 } \\
\text { L5 } \\
\text { L6 } \\
\text { L7 } \\
\text { LC }\end{array}$ & $\begin{array}{c}1(-) \\
4(+) \\
1(-) \\
4(+) \\
1(-) \\
4(+) \\
1(-) \\
4(+) \\
2.50\end{array}$ & $\begin{array}{c}0(-) \\
0(-) \\
40(+) \\
40(+) \\
0(-) \\
0(-) \\
40(+) \\
40(+) \\
20(0) \\
20\end{array}$ & $\begin{array}{c}2(-) \\
2(-) \\
2(-) \\
2(-) \\
16(+) \\
16(+) \\
16(+) \\
16(+) \\
8(0) \\
8\end{array}$ & $\begin{array}{c}0.026(+) \\
0(-) \\
0(-) \\
0.026(+) \\
0.026(+) \\
0(-) \\
0(-) \\
0.026(+) \\
0.013(0) \\
0\end{array}$ & $\begin{array}{l}\mathrm{KOH}(+) \\
\mathrm{NaOH}(+) \\
\mathrm{KOH}(+) \\
\mathrm{NaOH}(-) \\
\mathrm{NaOH}(-) \\
\mathrm{KOH}(+) \\
\mathrm{NaOH}(-) \\
\mathrm{KOH}(+) \\
\mathrm{KOH}(+) \\
\mathrm{NaOH}\end{array}$ \\
\hline
\end{tabular}


at $40^{\circ} \mathrm{C}$ with a flow rate of $20.4 \mathrm{ml} / \mathrm{h}$. A solution of $5 \mathrm{ml}$ of oligosaccharides $(\sim 5 \mathrm{mg} / \mathrm{ml})$ was loaded on the first column. Fractions of $4.1 \mathrm{ml}$ were collected at the end of the second column and assayed for neutral sugars as described in Analytical. Excluded and included volumes were determined using dextran blue and glucose, respectively.

A column of Sephacryl S500 $(1.6 \times 95 \mathrm{~cm})$ was eluted in ascending order by $0.1 \mathrm{M}$ sodium acetate buffer $\mathrm{pH}$ 4.5 with a flow rate of $60 \mathrm{ml} / \mathrm{h}$. Two millilitres of ASM1 solution $(6 \mathrm{mg} / \mathrm{ml})$ in acetate buffer were loaded on the column. Fractions $(5 \mathrm{ml})$ were collected and assayed for neutral sugars as described in the Analytical section. Excluded and included volumes were determined using amylopectin and glucose, respectively.

\section{Enzyme incubation}

A solution ( $5 \mathrm{mg} / \mathrm{ml}$ ) of ASM-1 or tamarind xyloglucan in sodium acetate buffer $0.1 \mathrm{M}, \mathrm{pH} 5$ was incubated in the presence of Cellulase $(0.3 \mathrm{nKat} / \mathrm{mg}$ of polysaccharide) for $24 \mathrm{~h}$ at $40^{\circ} \mathrm{C}$ in a hermetically closed tube, after which the enzyme was inactivated by $10 \mathrm{~min}$ in a boiling water bath.

\section{Analytical}

All results are presented on a dry weight basis, which was determined by drying at $120^{\circ} \mathrm{C}$ for $2 \mathrm{~h}$. Lignin was measured using an acidic detergent method as decribed earlier (Weightman et al., 1994). Neutral sugars were measured as alditol acetates after hydrolysis of samples. All samples were pretreated with $72 \%$ sulphuric acid (1 $\left.\mathrm{h}, 20^{\circ} \mathrm{C}\right)$ then hydrolysed in $2 \mathrm{~N}$ sulphuric acid $(3 \mathrm{~h}$, $100^{\circ} \mathrm{C}$ ) before conversion to alditol acetates (Englyst \& Cummings, 1984). The galacturonic acid (GalA) and total neutral sugars (NS) concentrations were measured by automated meta-hydroxy-diphenyl (Thibault, 1979) and orcinol assays (Tollier \& Robin, 1979) respectively. Corrections were made for the interference of uronic acids in the neutral sugars assay. Proteins were determined by a semi-automated Kjeldahl assay for insoluble materials (using $\mathrm{N} \times 6.25$ ) and by the Lowry assay (Lowry et al., 1951) in soluble samples. Fat was estimated as the material dissolved upon treatment of $1 \mathrm{~g}$ of apple pomace by $25 \mathrm{ml}$ of chloroform/methanol $(2 / 1$, $\mathrm{v} / \mathrm{v}$ ). Free sugars (glucose and fructose) were measured by HPAEC (Carbopac PAl column eluted with $150 \mathrm{~mm}$ $\mathrm{NaOH}$ at $1 \mathrm{ml} / \mathrm{min}$ ) in a cold water extract of the apple pomace. Ash was determined as the residue after incineration for $16 \mathrm{~h}$ at $550^{\circ} \mathrm{C}$ and $1 \mathrm{~h}$ at $900^{\circ} \mathrm{C}$.

\section{Physico-chemical properties}

Intrinsic viscosity $([\eta], \mathrm{ml} / \mathrm{g})$ was calculated by measuring the flow times of a solution of xyloglucan in $0.155 \mathrm{M}$ $\mathrm{NaCl}$ at $25.0 \pm 0.1^{\circ} \mathrm{C}$ in an automatic Ubbelohde visco- simeter (Amtec, Nice, France) and by using a double extrapolation to zero concentration based on Huggins and Kramer equations.

Foaming properties were estimated by mixing $5 \mathrm{ml}$ of solutions $(0.5-5 \mathrm{mg} / \mathrm{ml})$ of the ASM extract in a graduated tube $(10 \mathrm{ml})$ for $30 \mathrm{~s}$ with a Kinematica high speed homogeniser equipped with a $6 \mathrm{~mm}$ shaft; settings of the homogeniser and initial depth of plunging of the shaft were fixed $(7 ; 2 \mathrm{~cm})$. Initial height of the foam was read after a further $30 \mathrm{~s}$, and further measurements were taken at intervals during $1 \mathrm{~h}$ to follow the foam stability. In order to ascertain the contribution of contaminating protein, a sample of ASM was treated for one night at $25^{\circ} \mathrm{C}$ with $10 \mathrm{mg} / \mathrm{l}$ of protease in phosphate buffer ( $\mathrm{pH} 6 ; 0.05 \mathrm{M})$.

\section{Data analysis and statistical modelling}

The experimental range of variables was chosen from literature data. The effects of alkaline concentration $(1-4 \mathrm{M})$, temperature $\left(0-40^{\circ} \mathrm{C}\right)$, time $(2-16 \mathrm{~h})$, the presence of $\mathrm{NaBH}_{4}$, a reducing agent $(0-0.026 \mathrm{M})$ and type of alkali ( $\mathrm{KOH}$ and $\mathrm{NaOH})$, on yields of xyloglucan (ratio of the amount of xylose and glucose solubilised, determined by gas liquid chromatography (GLC), to the initial amounts of depectinised apple pomace) were estimated. Limits of the experimental range were brought into a $[-1 ;+1]$ interval according to the values reported in Table 1 (Box \& Draper, 1987). In order to minimise the number of experiments, a fractional factorial experimental design of resolution III was used $\left(2{ }_{\text {III }}^{5-2}\right)$, which led to eight runs, the conditions of which are given in Table 1. As the central point (LC) of the experimental design was repeated twice, the total number of experimental points was 10 . This design was used to minimise the number of runs, though it leads to a shortage of degrees of freedom in the analysis.

Analysis of variance was performed by using Stat works Software (Cricket Software, Philadelphia, USA) in order to determine the significance of the effects of these variables. Due to the fractional nature of the design, simple effects of these variables can be confused with the effect of the interaction of two others. Interaction effects were neglected when both variables had non-significant simple effects. An empirical model was built:

$$
Y_{\mathrm{e}}=b_{0}+b_{1} X_{1}+\ldots+b_{i} X_{i}+b_{12} X_{1} X_{2} \ldots+b_{i j} X_{i} X_{j}+\ldots
$$

where $Y_{\mathrm{e}}$ is the estimated response, $b_{\mathrm{o}}$ the model constant, $b_{i}$ and $b_{i j}$ the model coefficients reflecting the simple and interactive effects, respectively, and $X_{1} \ldots X_{i}$ the coded independent reaction variables. The coefficients $b$ were calculated by multiple linear regression and their significance checked by variance analysis.

One additional extraction was carried out with $6 \mathrm{M}$ $\mathrm{NaOH}$. 
Table 2. Yields (weight of the extract freeze-dried after dialysis, and xylose plus glucose in the extract, in $\% \mathrm{w} / \mathrm{dw}$ of the depectinised apple pomace) and composition of the alkaline extracts

\begin{tabular}{|c|c|c|c|c|c|c|c|c|c|c|c|}
\hline \multirow[t]{2}{*}{ Extract } & \multirow{2}{*}{$\begin{array}{c}\text { Yield } \\
\text { (extract) } \\
(\mathrm{mg} / \mathrm{g})\end{array}$} & \multirow{2}{*}{$\begin{array}{c}\text { Yield } \\
(\mathrm{Xyl}+\mathrm{Glc}) \\
(\mathrm{mg} / \mathrm{g})\end{array}$} & \multicolumn{9}{|c|}{ Composition (mg/g) } \\
\hline & & & Rha & Fuc & Ara & $\mathrm{Xyl}$ & Man & Gal & Glc & AUA & Proteins \\
\hline L0 & 5.3 & 1.8 & 16 & 5 & 16 & 132 & 38 & 112 & 209 & 72 & 291 \\
\hline L1 & 6.9 & 2.7 & 9 & 7 & 13 & 141 & 84 & 104 & 254 & 41 & 161 \\
\hline $\mathrm{L} 2$ & 9.1 & 0.6 & 6 & 3 & 11 & 31 & 20 & 23 & 36 & 54 & 408 \\
\hline L3 & 15.4 & 4.1 & 11 & 5 & 13 & 102 & 58 & 79 & 165 & 44 & 326 \\
\hline L4 & 6.6 & 2.4 & 19 & 5 & 17 & 146 & 52 & 109 & 218 & 50 & 517 \\
\hline L5 & 9.0 & 4.3 & 13 & 9 & 20 & 198 & 39 & 118 & 282 & 45 & 346 \\
\hline L6 & 20.4 & 2.8 & 8 & 3 & 10 & 65 & 10 & 42 & 72 & 25 & 774 \\
\hline L7 & 13.3 & 5.0 & 22 & 8 & 14 & 169 & 12 & 98 & 204 & 70 & 466 \\
\hline LCl & 12.5 & 3.6 & 13 & 7 & 14 & 128 & 21 & 82 & 164 & 51 & 607 \\
\hline LC2 & 12.5 & 3.9 & 8 & 7 & 12 & 128 & 23 & 81 & 186 & 45 & 639 \\
\hline S6M & 19.9 & 8.1 & 13 & 9 & 13 & 157 & 64 & 102 & 252 & 62 & 589 \\
\hline
\end{tabular}

\section{RESULTS AND DISCUSSION}

\section{Composition of the depectinised apple pomace}

The composition of the depectinised apple pomace was similar to previously reported data (Renard \& Thibault, 1991). It was rich in glucose $(290 \mathrm{mg} / \mathrm{g} \mathrm{dw})$ and xylose $(83 \mathrm{mg} / \mathrm{g})$, and contained much less galacturonic acid $(79 \mathrm{mg} / \mathrm{g})$, arabinose $(21 \mathrm{mg} / \mathrm{g})$, galactose $(39 \mathrm{mg} / \mathrm{g})$ and rhamnose $(7 \mathrm{mg} / \mathrm{g})$ than non-extracted apple pomaces (Renard \& Thibault, 1991). However, the content of galacturonic acid was still far from negligible. Indeed, hot acid treatments as used in the industry extract only about half of the pectins. The depectinised apple pomace was rich in proteins $(105 \mathrm{mg} / \mathrm{g})$ and remarkably rich in 'lignin' (186 mg/g). The 'lignin' was measured here as the residue insoluble in concentrated sulphuric acid after an acid detergent treatment, and is actually mostly composed of polyphenols formed during the juice extraction. These polyphenols then precipitate on the cell wall matrix, where they persist after further drying and extraction treatments. The depectinised apple pomace contained a minor amount of free sugars (fructose $10 \mathrm{mg} / \mathrm{g}$, glucose $8 \mathrm{mg} / \mathrm{g}$ ), in spite of the juice and pectin extraction treatments, and also some fucose (3 $\mathrm{mg} / \mathrm{g})$, mannose $(2 \mathrm{mg} / \mathrm{g})$, ash $(20 \mathrm{mg} / \mathrm{g})$ and fat $(68 \mathrm{mg} / \mathrm{g})$.

\section{Extractions following the experimental design}

Results of the extractions are given in Table 2, and their interpretation in Table 3. The low number of runs, used to limit the number of lengthy extraction procedures, also limits the confidence with which conclusions can be drawn from the results, especially concerning interaction effects.

The central point of the experimental design (LC) was carried out in duplicate and was reproducible, both for yield and composition. Extraction yields were low, varying in weight of freeze-dried material from 5.3 to $20.4 \%$, and in the yield of xylose plus glucose from 0.6 to $5.0 \%$ of the depectinised apple pomace. As the composition and especially the ratio of proteins to carbohydrates were very variable, we chose to use the yields calculated as xylose plus glucose for testing the experimental design.

The most significant $(p<0.05)$ effects were molarity of alkali (effect 1) and duration of extraction (effect 3). Temperature had no significant effect. The type of alkali (effect 5) had no significant effect in the experimental range tested. The effect of $\mathrm{NaBH}_{4}$ can be considered significant at the 0.1 level. However it cannot be distinguished from an interaction effect of concentration and temperature, due to the low number of points in the experimental design.

In spite of this limitation, an empirical model of the extraction was obtained by linear regression, using only concentration of alkali and duration of extraction: $Y_{\mathrm{e}}=3.0+(1.1 \times$ Molarity $)+(0.7 \times$ Duration $)\left(r^{2}=0.9\right)$ (with molarity and duration in coded variables). This model is highly significant $(<0.001)$ and gave a reasonable prediction of the yield at the central point $\left(Y_{\mathrm{e}}=3\right.$ for $Y_{\mathrm{m}}=3.6$ and 3.9). The model indicates that yield in

Table 3. Results of the experimental design

\begin{tabular}{lrcc}
\hline Estimated effect & Code & $\begin{array}{c}\text { Value of } \\
\text { the effect }\end{array}$ & $p$ Value \\
\hline Average & $b_{0}$ & 3.0 & $<0.05$ \\
$\begin{array}{l}\text { Concentration of alkali } \\
\text { Temperature }\end{array}$ & 2 & 2.1 & $<0.05$ \\
$\begin{array}{l}\text { Duration of extraction } \\
\text { Interaction of concentration } \\
\quad \text { and temperature, or NaBH }\end{array} 4$ & 12 or 4 & 0.3 & $>0.1$ \\
$\quad \begin{array}{l}\text { Interaction of concentration } \\
\text { and duration, or type of alkali }\end{array}$ & 13 or 5 & -0.1 & $>0.25$ \\
$\begin{array}{l}\text { Interaction of temperature } \\
\quad \text { and duration }\end{array}$ & 23 & 0.2 & $>0.1$ \\
$\begin{array}{l}\text { Interaction of concentration, } \\
\text { temperature and duration }\end{array}$ & 123 & -0.6 & $>0.1$ \\
\hline
\end{tabular}




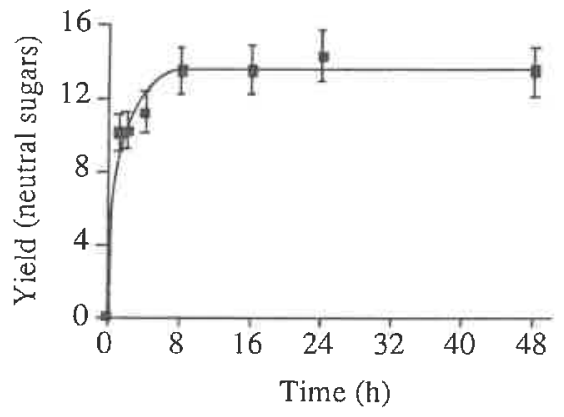

Fig. 1. Kinetics of extraction of xyloglucan from depectinised apple pomace. The yields were calculated from the neutral sugars concentration and the volume measured after centrifugation and dialysis.

xyloghucan increases with higher concentrations of alkali and longer extraction times. Indeed, increased concentrations of alkali probably have increased chaotropic effects, thus rupturing the $\mathrm{H}$-bonds between xyloglucans and cellulose. The effect of duration of extraction could be due to diffusion either of the alkali inside the cell walls, or of solubilised xyloglucans out of the wall matrix.

In order to confirm the effect of duration, a kinetics study was carried out, in which the yield of neutral sugars was measured by colorimetry (Fig. 1). The conditions used were $4 \mathrm{M} \mathrm{KOH}$ at $40^{\circ} \mathrm{C}$, with $\mathrm{NaBH}_{4}$. The yields in neutral sugars increased for times up to 8 $h$, and then plateaued. An extraction duration of $16 \mathrm{~h}$ increased the yield by $30 \%$ compared to an extraction duration of $2 \mathrm{~h}$, confirming the effect observed in the experimental design. These kinetics explain also why yield values predicted at the central point were lower than the measured values, as the predicted values used a linear extrapolation for variation of the yield with time of extraction.

All these extracts contained essentially proteins and carbohydrates, in varying proportions. The carbohydrate fractions were composed mostly of glucose and xylose, confirming extraction of a xyloglucan. They contained also fucose and galactose, as expected in apple, where these sugars are present in the sidechains of the xyloglucan (Renard et al., 1991, 1992; Voragen et al., 1986). They were still contaminated by some pectic material (galacturonic acid, arabinose and rhamnose), and some mannose. A low molecular weight mannan has been reported as a minor hemi- cellulose of apple (Renard et al., 1991; Voragen et al., 1986).

\section{Larger scale extraction: yields and composition of the extracts}

A preparative extraction was carried out under conditions selected from the experimental design: $4 \mathrm{M}$ alkali $(\mathrm{KOH})$ at $40^{\circ} \mathrm{C}$ for $16 \mathrm{~h}$, with $\mathrm{NaBH}_{4}$. In addition, we have tested the method described by Edelman \& Fry (1992), who concluded that better yields in xyloglucan could be obtained by washing the residue from a first alkaline extraction with water, rather than by a second alkaline treatment.

The yield obtained for ASM was slightly lower than that obtained from the extract $\mathrm{L} 7$ in the experimental design, probably due to change of scale (Table 4). The composition of ASM was very close to that of L7, with as main differences, lower glucose and slightly higher protein concentrations. The yield of ASM was lower than the previously reported results for extraction of xyloglucans from apple cell walls (Aspinall \& Fanous, 1984; Stevens \& Selvendran, 1984; Ruperez et al., 1985; Voragen et al., 1986; Renard et al., 1991). However these authors worked on cell wall material isolated in the laboratory from fresh apple, therefore, without extensive polymerisation of polyphenols. They very often used a sequential extraction (Stevens \& Selvendran, 1984; Ruperez et al., 1985; Renard et al., 1991), or a chlorite pretreatment (Aspinall \& Fanous, 1984).

ASM was rich in proteins, as reported by Renard $e t$ al. (1991). The alkali resolubilised a major amount of the intracellular proteins that had precipitated in the apple pomace during its drying. The sugar composition of the extract showed the presence of a fucogalactoxyloglucan, as expected, with minor contamination by pectic material and some mannan.

The treatment with water (WSM) solubilised only minor amounts of material and even less xyloglucans (Table 4). In contrast to the results from Edelman \& Fry (1992), who reported extraction of additional xyloglucan by water, the amounts of xylose plus glucose were low, and their relative amounts did not correspond to a xyloglucan. Edelman \& Fry (1992) also report that the water-extractable material is rich in glycuronans, which does agree with the high content of uronic acids in WSM.

Table 4. Yields and composition of the extracts of the larger scale extraction

\begin{tabular}{|c|c|c|c|c|c|c|c|c|c|c|c|}
\hline \multirow[t]{2}{*}{ Extract } & \multirow{2}{*}{$\begin{array}{c}\text { Yield } \\
\text { (extract) } \\
\text { (mg/g) }\end{array}$} & \multirow{2}{*}{$\begin{array}{c}\text { Yield } \\
(\mathrm{xyl}+\mathrm{glc}) \\
(\mathrm{mg} / \mathrm{g})\end{array}$} & \multicolumn{9}{|c|}{ Composition (mg/g) } \\
\hline & & & Rha & Fuc & Ara & Xyl & Man & Gal & Glc & AUA & Proteins \\
\hline ASM & 13.5 & 4.8 & 12 & 8 & 12 & 177 & 12 & 88 & 175 & 75 & 441 \\
\hline WSM & 4.3 & 0.8 & 6 & 0 & 7 & 27 & 4 & 19 & 1 & 198 & 247 \\
\hline
\end{tabular}

ASM, alkali-soluble material; WSM, water soluble material; AUA, anhydro uronic acids 
Table 5. Foaming properties of ASM, the alkaline extract from depectinised apple pomace: height of the foam and its half-life

\begin{tabular}{lccccccc}
\hline Sample & $5 \mathrm{~g} / 1$ & $4 \mathrm{~g} / 1$ & $3 \mathrm{~g} / 1$ & $2 \mathrm{~g} / 1$ & $1 \mathrm{~g} / 1$ & $0.5 \mathrm{~g} / 1$ & $\begin{array}{c}5 \mathrm{~g} / 1- \\
\text { protease }\end{array}$ \\
\hline Initial height (cm) & $3.8 \pm 0.15^{a}$ & $\begin{array}{c}3.3 \pm 0.17^{b} \\
4 \pm 1\end{array}$ & $\begin{array}{l}3.0 \pm 0.16^{b} \\
\text { Half life (min) }\end{array}$ & $\begin{array}{l}2.1 \pm 0.11^{b} \\
1.5\end{array}$ & $\begin{array}{c}0.9 \pm 0.00^{a} \\
\text { nd }\end{array}$ & $\begin{array}{c}0.8 \\
\text { nd }\end{array}$ & $\begin{array}{l}2.6 \\
\text { nd }\end{array}$ \\
\hline
\end{tabular}

nd, not determined ( $>1 \mathrm{~h})$.

$a_{n=3}$.

${ }^{b} n=5$.

\section{Foaming properties of the alkaline extracts}

While trying to measure the intrinsic viscosities of the raw extracts from the experimental design, we were foiled by the formation of a stable foam inside the viscometer. These foaming properties were quantified on the larger scale extract ASM using a method adapted from that described by Dea \& Madden (1986). The results (height of the foam and half life) are presented in Table 5 . Under the same conditions, a solution $(5 \mathrm{~g} / 1)$ of bovine serum albumin produced a foam height of $7 \mathrm{~cm}$. The foam obtained was heterogeneous, with both small and large bubbles, especially for the higher concentrations, for which the half-lives were thus shorter, with a rapid disappearance of the larger bubbles while fine foam persisted for $>0.5 \mathrm{~h}$. A typical foam disappearance pattern is given in Fig. 2. Treatment with protease led to a decrease in the amount of foam, indicating a role for these macromolecules, and to a much better persistence of the foam, with a half-life $>1 \mathrm{~h}$.

\section{Fractionation on DEAE Sepharose CL-6B}

The fucogalactoxyloglucan present in ASM was purified by ion-exchange chromatography (Fig. 3). Three fractions were obtained for this extract: a major, nonretained fraction and two retained fractions with increasing proportions of uronic acids. The first fraction, ASM-1, was almost exclusively neutral and its composition was that of a fucogalactoxyloglucan, with a molar ratio fucose:galactose:xylose:glucose of 0.25:1.5:4:6 (Table 6). This result differed from the

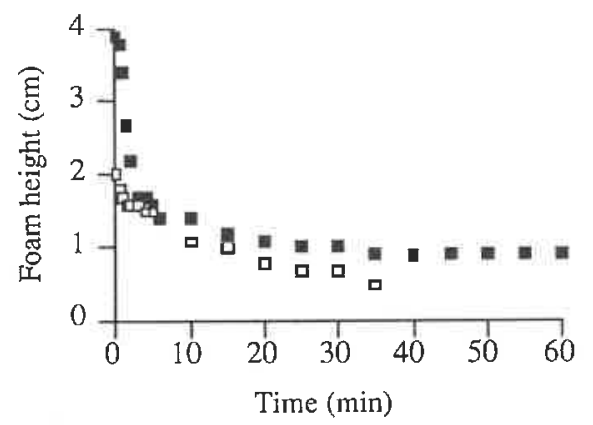

Fig. 2. Evolution of the height of the foam generated by alkali-soluble material (ASM): $\mathbf{0}$, at $5 \mathrm{~g} / \mathrm{l} ; \square$, at $2 \mathrm{~g} / \mathrm{l}$. molar ratio (1:1.5:4:6) obtained by Renard et al. (1991) by a lower amount of fucose, which could be due to hydrolysis of the glycosidic linkages between fucose and galactose during the acidic treatment used for extraction of pectins. The intrinsic viscosity of fraction ASM-1 was only of $240 \mathrm{ml} / \mathrm{g}$ (with a Huggins coefficient of 0.4 ), considerably lower than the value of $2915 \mathrm{ml} / \mathrm{g}$ determined by Gidley et al. (1991) for tamarind xyloglucan. Chromatography of ASM-1 on Sephacryl S500 showed one symmetrical peak, eluting at a $K_{\mathrm{av}}$ of 0.75 (Fig. 3), close to the $K_{\mathrm{av}}$ observed for fucogalactoxyloglucan extracted from fresh apple cell walls (0.6-0.7; Renard et al., 1991).

ASM-2 was poor in uronic acids and rich in xylose and galactose, and ASM-3 was rich in uronic acids and galactose. This last fraction did not appear homogeneous, with an increased uronic acid proportion at the higher elution volumes. From its composition, it seems likely that ASM-3 corresponded to residual pectins in the depectinised apple pomace.

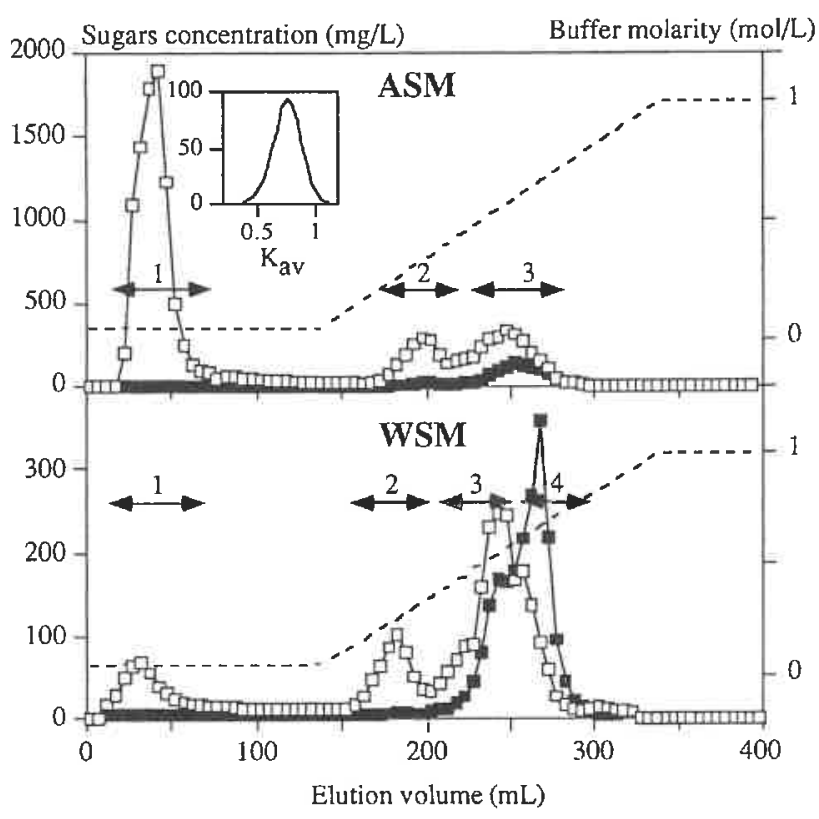

Fig. 3. Elution patterns of alkali-soluble material (ASM) and water-soluble material (WSM) on DEAE Sepharose CL-6B eluted with acetate buffer $\mathrm{pH}$ 4.8. , uronic acids; $\square$, neutral sugars; - , buffer. Inset: elution pattern of ASM-1 on Sephacryl S 500. -, total sugars. 
Table 6. Sugar composition (mol\%) of the fractions from DEAE Sepharose CL-6B chromatography of ASM and WSM

\begin{tabular}{lrlrrrrrr}
\hline & Rha & Fuc & Ara & Xyl & Man & Gal & Glc & AUA \\
\hline ASM & & & & & & & & \\
ASM-1 & 0.5 & 1.8 & 1.4 & 34.1 & 2.5 & 14.1 & 44.8 & 0.8 \\
ASM-2 & 2.3 & 0.5 & 5.5 & 49.7 & 1.8 & 18.7 & 12.4 & 9.1 \\
ASM-3 & 14.0 & 0.8 & 2.9 & 20.0 & 0.5 & 18.2 & 10.4 & 33.2 \\
WSM & & & & & & & & \\
WSM-1 & 2.5 & nd & 4.9 & 31.5 & 12.2 & 18.5 & 25.6 & 4.8 \\
WSM-2 & 3.3 & nd & 13.3 & 48.4 & 4.6 & 12.5 & 7.4 & 10.5 \\
WSM-3 & 8.5 & nd & 2.0 & 21.1 & 1.4 & 9.3 & 2.2 & 55.5 \\
WSM-4 & 3.2 & nd & 1.0 & 5.9 & 1.1 & 2.6 & 1.5 & 84.7 \\
\hline
\end{tabular}

For identification of the fractions see Fig. 3. nd, not detected.

Fractionation of WSM (Fig. 3) showed four fractions, none of which was a xyloglucan, as expected from the composition of this material (Table 4). The recovery after chromatography was poor ( $30 \%$ for uronic acids and $55 \%$ for neutral sugars), and a major part of the material was retained on the column. Such low yields are frequently encountered for macromolecules with high charge densities. From the composition of WSM and its fractions, this water-soluble material appears to consist mostly of residual pectins, not extracted by the hot acid treatment, and de-esterified during the alkaline extraction of xyloglucan.

\section{Structural characterisation of the fucogalactoxyloglucan fraction ASM-1}

The digest of ASM-1 by cellulase showed three main peaks (Fig. 4), eluting between $K_{\mathrm{av}} 0.50$ and 0.62 on combined Bio-Gel P-4 and P-2. All fractions eluting between $K_{\mathrm{av}} 0.1$ and 1 contained xylose and glucose (Table 7), confirming that ASM-1 was composed of a xyloglucan, as opposed to a mixture of xylan and glucan. Calibration of the column was carried out with

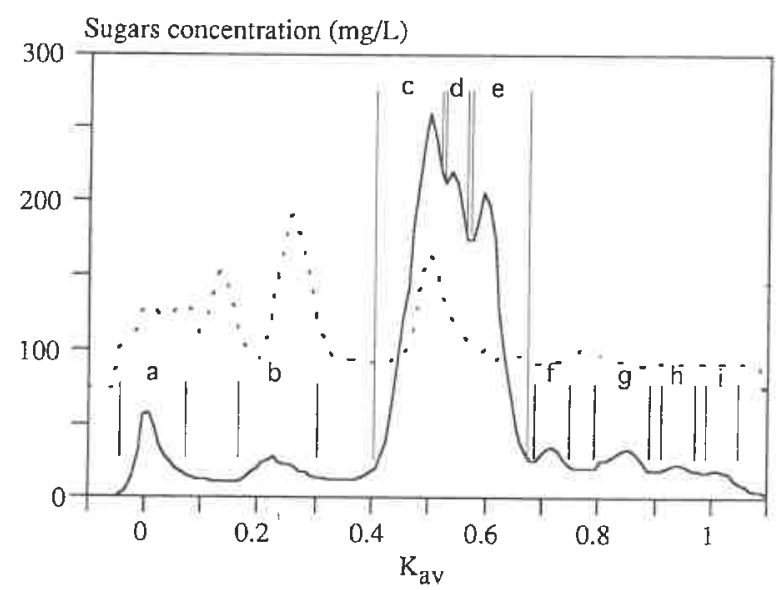

Fig. 4. Elution patterns of xyloglucan oligomers on Biogel P-4 $+\mathrm{P}-2$ columns eluted with distilled water at $40^{\circ} \mathrm{C}$ - digest of ASM-1 by cellulase; ---, digest of tamarind xyloglucan by cellulase.
Table 7. Sugar compositions ( $\mathrm{mol} \%$ ) of the fractions from BioGel P-4 + P-2 chromatography of the digest of ASM-1 by cellulase

\begin{tabular}{lccccccc}
\hline & Rha & Fuc & Ara & Xyl & Man & Gal & Glc \\
\hline ASM-1 a & 2 & 1 & 8 & 10 & 4 & 52 & 23 \\
ASM-1 b & 1 & 4 & 5 & 31 & 1 & 18 & 41 \\
ASM-1 c & tr. & 4 & 1 & 33 & tr. & 19 & 42 \\
ASM-1 d & tr. & 1 & 1 & 36 & 1 & 13 & 48 \\
ASM-1 e & tr. & tr. & tr. & 41 & 1 & 4 & 52 \\
ASM-1 f & 1 & 1 & 1 & 31 & 7 & 10 & 49 \\
ASM-1 g & tr. & nd & 1 & 31 & 16 & 1 & 51 \\
ASM-1 h & nd & nd & nd & 28 & 28 & nd & 44 \\
ASM-1 i & 1 & nd & 4 & 13 & 4 & nd & 78 \\
\hline
\end{tabular}

For identification of the fractions see Fig. 4 , tr., $\leqslant 0.5 \%$; nd, not detected.

xyloglucan oligomers from tamarind. The peak at the highest $K_{\text {av }}$ from tamarind xyloglucan oligomers, which contained $[\mathrm{Xyl}(\mathrm{Glc})]_{3}-\mathrm{Glc}$, has the same $K_{\mathrm{av}}$ as fraction ASM-1 c, the largest of the main fractions from ASM-1. The three fractions ASM- $1 \mathrm{c}, \mathrm{d}$ and e showed decreasing amounts of galactose, and only fraction ASM-1 c contained more than $1 \mathrm{~mol} \%$ fucose, in contrast to results obtained earlier on xyloglucans from apple cell walls (Renard et al., 1992). Lack of fucose, and the smaller size of oligomers, is probably due to the acid treatment used for pectin extraction. It is difficult to say more about these fractions, as they are certainly not pure: ASM-1 $\mathrm{d}$ is heavily contaminated by its neighbours, and both ASM-1 c and e present shoulders. Of the minor components of the ASM-1 digest, ASM-1 a, eluted at the void volume, was enriched in rhamnose, arabinose and galactose, and might be residual pectic material. Mannose, which represented $2.5 \mathrm{~mol} \%$ of ASM-1, is mostly found in small oligomers of fractions ASM-1 $f$, $g$ and $h$.

\section{CONCLUSION}

Concentrated alkali were able to extract fucogalactoxyloglucans from the residue of apple pectin extraction. However, the yields were low, even under the best conditions, and the xyloglucan showed a low intrinsic viscosity, so that this is certainly not a good source of thickening agent. The alkaline extract showed some foam stabilising properties.

The yields of extraction of xyloglucan increased with the concentration of alkali and time, up to an extraction time of about $10 \mathrm{~h}$. No xyloglucan was extracted during washing with water, in contrast to the conclusions of Edelman \& Fry (1992). Compared to the xyloglucans extracted from fresh apple cell walls, the harsh acid treatment used during industrial extraction of pectins had led to a loss of fucose and probably also of xylose, as could be seen from oligomers produced during digestion by a cellulase. 


\section{ACKNOWLEDGEMENTS}

The authors thank Dr. G. DellaValle for his help in elaboration and statistical interpretation of the experimental design.

\section{REFERENCES}

Aspinall, G.O. \& Fanous, H.K. (1984). Structural investigations on the non-starchy polysaccharides of apples. Carbohydr. Polym., 4, 193-214.

Box, G.E.P. \& Draper, N.D. (1987). Empirical Model-building and Response Surfaces. John Wiley, New York.

Dea, I.C.M. \& Madden, J.K. (1986). Acetylated pectic polysaccharides of sugar-beet. Food Hydrocolloids, 1, 7188.

Edelman, H.G. \& Fry, S.C. (1992). Factors that affect the extraction of xyloglucan from the primary cell walls of suspension-cultured rose cells. Carbohydr. Res., 228, 423-431.

Englyst, H.N. \& Cummings, J.H. (1984). Simplified method for the measurement of total non-starch polysaccharides by gas-liquid chromatography of constituent sugars as alditol acetates. Analyst, 109, 937-942.

Fry, S.C., Smith, R.C., Renwick, K.F., Martin, D.J., Hodge, S.K. \& Matthews, K.J. (1992). Xyloglucan endotransglycosylase, a new wall-loosening enzyme activity from plants. Biochem. J., 282, 821-828.

Gidley, M.L, Lillford, P.J., Rowlands, D.W., Lang, R., Dentini, M., Crescenzi, V., Edwards, M., Fanutti, C. \& Reid, J.S.G. (1991). Structure and solution properties of tamarind-seed polysaccharide. Carbohydr. Res., 227, 299314.

Hayashi, T. (1989). Xyloglucans in the primary cell wall. Ann. Rev. Plant Physiol., 40, 139-168.

Kooiman, P. (1960). On the occurence of amyloids in plant seeds. Acta Botanica Neerlandica, 9, 208-219.

Lowry, G.H., Rosebrough, N.J., Farr, L.A. \& Randall, R.J. (1951). Protein measurement with the folin phenol reagent. J. Biol. Chem., 193, 265-275.

McDougall, G.J. \& Fry, S.C. (1989). Structure-activity relationships for xyloglucan oligosaccharides with antiauxin activity. Plant Physiol., 89, 883-887.

McNeil, M., Darvill, A.G., Fry, S.C. \& Albersheim, P. (1984). Structure and function of the primary cell walls of plants. Ann. Rev. Biochem., 53, 625-663.

Nishitani, K. \& Tominaga, R. (1992). Endo-xyloglucan transferase, a novel class of glycosyltransferase that catalyses transfer of a segment of xyloglucan molecule to another xyloglucan molecule $J$. Biol. Chem., 267, 2105821064.

Rao, P.S. (1959) Tamarind. In Industrial Gums, Polysaccharides and their Derivatives, eds R.L. Whitler and J.N. BeMiller. Academic Press, NY, pp. 461-504.

Renard, C.M.G.C., Lomax, J.A. \& Boon, J.J. (1992). Applefruit xyloglucans: a comparative study of enzyme digests of whole cell walls and of alkali-extracted xyloglucans. Carbohydr. Res., 232, 303-320.

Renard, C.M.G.C. \& Thibault, J.-F. (1991). Composition and physico-chemical properties of apple fibres from fresh fruits and industrial products. Lebensm.-Wiss. u. -Technol., 24, $523-527$.

Renard, C.M.G.C., Voragen, A.G.L., Thibault, J-F. \& Pilnik, W. (1991). Studies on apple protopectin. IV: Apple xyloglucans and influence of pectin extraction treatments on their solubility. Carbohydr. Polym., 15, 387-403.

Ruperez, P., Selvendran, R.R. \& Stevens, B.J.H. (1985). Investigation of the heterogeneity of xyloglucans from the cell walls of apple. Carbohydr. Res., 142, 107-113.

Stevens, B.J.H. \& Selvendran, R.R. (1984). Structural features of cell-wall polysaccharides of the apple. Carbohydr. Res., $135,155-166$.

Thibault, J-F. (1979). Automatisation du dosage des substances pectiques par la méthode au méta-hydroxydiphenyl. Lebensm. - Wiss. u. -Technol., 12, 247-251.

Tollier, M.-T. \& Robin, J-P. (1979). Adaptation de la méthode à l'orcinol sulfurique au dosage automatique des oses neutres et totaux. Ann. Technol. Agric., 28, 1-15.

Voragen, F.G.J., Schols, H.A. \& Pilnik, W. (1986). Structural features of the hemicellulose polymers of apple. $Z$. Lebensm. Unters. Forsch., 183, 105-110.

Weightman, R.M., Renard, C.M.G.C. \& Thibault, J-F. (1994). Structure and properties of the polysaccharides from pea hulls. Part 1: Chemical extraction and fractionation of the polysaccharides. Carbohydr. Polym., 24, 139-148. 